\title{
SESJA NAUKOWA: „BL. AUGUST CZARTORYSKI, SALEZJANIN (1858-1893). POWOŁANIE DO SŁUŻBY W KOŚCIELE WCZORAJ I DZIŚ (W PIERWSZĄ ROCZNICE BEATYFIKACJI)", KATOLICKI UNIWERSYTET LUBELSKI, LUBLIN 25 KWIETNIA 2005 R.
}

„August Czartoryski, młody książę, wypracował skuteczną metodę rozeznawania zamysłów Bożych. Wszystkie pytania i rozterki przedstawiał najpierw Bogu w modlitwie, a potem w duchu posłuszeństwa szedł za radą swoich duchowych przewodników. (...) Przykład jego świętości pragnę pozostawić szczególnie ludziom młodym, którzy dziś szukają sposobu na odkrywanie woli Bożej odnośnie do ich życia i pragną wiernie podążać każdego dnia za głosem Bożym”. Przywołując powyższe słowa papieża Jana Pawła II z homilii beatyfikacyjnej, ks. prof. dr hab. Stanisław Wilk SDB - Rektor KUL otworzył sesję naukową Bt. August Czartoryski, salezjanin (1858-1893). Powołanie do służby w Kościele wczoraj $i$ dziś (W pierwsza rocznice beatyfikacji). Po nim głos zabrał Metropolita Lubelski abp prof. dr hab. Józef Życiński - Wielki Kanclerz KUL. W swoim słowie do zebranych w auli im. Stefana kardynała Wyszyńskiego zwrócił on szczególną uwagę na naturalną syntezę dwóch profili w postaci Augusta Czartoryskiego - polskości i europejskości.

Pierwszą część sesji otworzył referat pt. Hotel Lambert - dom i centrum polityczne Adama Jerzego i Władysława Czartoryskich wygłoszony przez prof. dr. hab. Jana Ziółka (Lublin KUL), w którym przedstawił on środowisko domowe, w którym przyszedł na świat i wychowywał się bł. August Czartoryski. Następnie głos zabrał mgr Paweł Sieradzki (Lublin KUL), który w wystąpieniu zatytułowanym Ksiażę August w perspektywie planów rodzinnych, ukazał skomplikowaną dynamikę relacji ojciec - syn wpisaną w działalność Czartoryskich w Galicji w II połowie XIX w. W trzeciej prelekcji pt. Patron trudnego powołania ks. dr hab. Jarosław M. Popławski (Lublin KUL) przedstawił głęboko teologiczny wymiar życia bł. Augusta Czartoryskiego, którego konsekwencją było wstąpienie do zgromadzenia salezjańskiego i przyjęcie w nim święceń kapłańskich. Tę część sesji zamknął wicepostulator procesu beatyfikacyjnego ks. Michał Szafarski SDB (Kraków) odczytem Proces beatyfikacyjny i wyniesienie do chwaty ottarzy ks. Au- 
gusta Czartoryskiego przestawiając kulisy wydarzeń zwieńczonych uroczystością beatyfikacyjną dnia 25 kwietnia 2004 r. na watykańskim Placu św. Piotra.

W południe w kościele akademickim KUL została odprawiona Msza św., której przewodniczył i homilię wygłosił biskup sosnowiecki dr Adam Śmigielski SDB. Oprawę muzyczną liturgii przygotował Chór Męski Salezjańskiej Ogólnokształcącej Szkoły Muzycznej II stopnia w Lutomiersku.

Po przerwie obiadowej, nastąpiła druga część sesji, którą rozpoczęła dyskusja panelowa. Jej tematem przewodnim był szeroko rozumiany obecny stan powołań w kościele powszechnym w perspektywie życia bł. ks. Augusta Czartoryskiego SDB. Moderatorem dyskusji był bp dr Stefan Regmunt (Legnica) delegat Episkopatu Polski ds powołań. Pozostałymi osobami zaproszonymi do uczestnictwa w rozważanich były panie Anna z Czartoryskich Radziwiłłowa (Warszawa) i dr Barbara Czartoryska - prezes Związku Czartoryskich herbu Pogoń (Warszawa) oraz o. dr hab. Andrzej Derdziuk OFMCap (Lublin KUL) i ks. dr Marek Dziewiecki (Radom) - Krajowy Duszpasterz Powołań. Na temat problematyki powołaniowej w Europie Zachodniej ze szczególnym uwzględnieniem sytuacji w jakiej znalazł się Kościół w Hiszpanii wypowiadali się ks. prof. dr Javier Velasco (Uniwersytyet La Rioja w Logroňo, Hiszpania) i dr hab. Cezary Taracha (Lublin KUL).

Dyskusję panelową zwieńczył koncert organowy i występ Chóru Męskiego Salezjańskiej Ogólnokształcącej Szkoły Muzycznej II stopnia w Lutomiersku.

Ostatni punkt obchodów pierwszej rocznicy beatyfikacji ks. Augusta Czartoryskiego dokonał się $\mathrm{w}$ godzinach wieczornych na dziedzińcu KUL. Było nim widowisko Teatru ITP zatytułowane Niebieski ptak - oparte na ewangelicznej przypowieści o perle.

Organizatorami sesji były: II Katedra Historii Nowożytnej KUL, Katedra Historii Zakonów KUL, Towarzystwo Naukowe KUL, przy współudziale Instytutu Hiszpańsko-Polskiego w Lublinie oraz Salezjanów pracujących i studiujących na KUL-u. 